\title{
Recent benthonic foraminifera from the Western Antarctic Ocean
}

\author{
R. W. JONES' \& C. A. PUDSEY ${ }^{2}$ \\ ${ }^{1}$ BP Exploration (Frontier \& International), 5 Long Walk, Stockley Park, Uxbridge, Middlesex UB11 1BP, UK. \\ ${ }^{2}$ British Antarctic Survey, High Cross, Madingley Road, Cambridge CB3 OET, UK.
}

\begin{abstract}
Approximately 60 species of benthonic foraminifera are recorded from 14 samples collected by the RRS Discovery from water depths of $200-4200 \mathrm{~m}$ on the Antarctic Peninsula Shelf and Slope and adjacent areas of the Western Antarctic Ocean. Discussion focuses firstly on benthonic foraminiferal abundance, diversity and assemblage composition and the effects of calcite dissolution and, secondly, on the characteristic assemblages of the study area and their relationships to water-masses. J. Micropalaeontol. 13(1): 17-23, September 1994.
\end{abstract}

\section{INTRODUCTION \\ Previous studies}

In contrast to the Arctic, the Antarctic or Southern Ocean (i.e. the area between Antarctica and the Subtropical Convergence at about $40-50^{\circ} \mathrm{S}$ ) received scant attention from foraminiferologists in the last century.

The earliest account of the Recent benthonic foraminifera from the area is that of Brady (1884), who described the material collected from around Heard Island and Kerguelen Island during the cruise of HMS Challenger (1872-6).

Most of the pioneering work was done in the early part of this century by, among others, Heron-Allen \& Earland (1922, 1929, 1932) and Earland (1933, 1934, 1936) (foraminifera collected on the various Discovery $I$ and $I I$, Scotia, Terra Nova and William Scoresby Expeditions of the 1920s), Wiesner (1931) (German South Polar Expedition of 1901-3), Parr (1950) (BANZ Antarctic Research Expedition of 1929--31) and Shchedrina (1979) (Soviet Antarctic Expedition of 1955-66). The trochamminacean foraminifera described by Heron-Allen and Earland have recently been comprehensively revised by Brönnimann \& Whittaker (1988).

Subsequent work has been undertaken by, among others, Saidova (1961), Bandy \& Echols (1964) and Theyer (1971) (general); McKnight (1962), Pflum (1966), Kennett (1967, 1968), Echols \& Kennett (1973), Fillon (1974), Kellogg et al. (1979), Osterman \& Kellogg (1979), Milam \& Anderson (1981), Nomura (1983, 1984) (surface and shallow subsurface sediments); Quilty (1985) and Schroder-Adams (1990) (Eastern Antarctica) (Lutzow-Holm Bay, Prydz Bay, Adelie-George V Land and Ross Sea); Pflum (1966), Echols (1971), Herb (1971), Anderson (1975), Lena (1975, 1980), Pudsey et al. (1987) (surface and shallow subsurface sediments); Mackensen et al. (1990) (Western Antarctica) (South Sandwich, Scotia Sea, South Orkneys, Drake Passage, Weddell Sea, Antarctic Peninsula, Bellingshausen Sea and Amundsen Sea); and Lindenberg \& Auras (1984) (Kerguelen Plateau).

The most recent reference to hand is that of Murray (1991), which provides a concise and extremely useful synthesis of ecological information on nearshore and shelf to deep sea areas (with specific reference to the Weddell Sea, Prydz Bay, McMurdo Sound and the Ross Sea, the Amundsen and Bellingshausen Seas, and the Drake Passage and Scotia Seas).

The high-resolution diatom stratigraphy of the Quarternary of the Scotia Sea is discussed by Jordan \& Pudsey (1992).

The geology of Antarctica is discussed by, among others, St John (1990).

\section{Present study}

The present study focuses on samples collected in the Western Antarctic Ocean on RRS Discovery Cruises 154 (January-April 1985) and 172 (December 1987-March 1988) (Fig. 1).

The studied surface samples comprised seven from the Antarctic Peninsula Shelf, two from South Sandwich (one of which could, in fact, be of Latest Pliocene-Early Pleistocene rather than Holocene age), two from the Drake Passage, two from the Scotia Sea, and one from the Antarctic Peninsula Slope. Full location, depth and lithological details are given on Table 1.

Full suites of oceanographic data pertaining to the study sites are held by the British Antarctic Survey (BAS) in Cambridge. The bottom temperature and current velocity data documented in the succeeding section are extracted from the BAS database.

The hydrographic regime of the study area is discussed by Gordon (1971), Deacon (1979), Kilworth (1983), Patterson \& Sievers (1980), Foster \& Middleton (1984), Sievers \& Nowlin (1984), Nowlin \& Zenk (1988), Pudsey et al. (1988) and Jordan \& Pudsey (1992) (and references therein). The palaeohydrographic regime is discussed by Barker et al. (1988).

There are two deep water-masses in the study area at the present time, namely Circumpolar Deep Water (CPDW) and Antarctic Bottom Water (AABW). CPDW (with bottom potential temperature $\theta=0.0-1.0^{\circ} \mathrm{C}$ and salinity $S=34.70-34.73$ ppt: Sievers \& Nowlin, 1984) flows eastward through the Drake Passage and the Scotia Sea as the Antarctic Circumpolar Current. This current is approximately coincident with the Polar Front (Fig. 1), and passes 


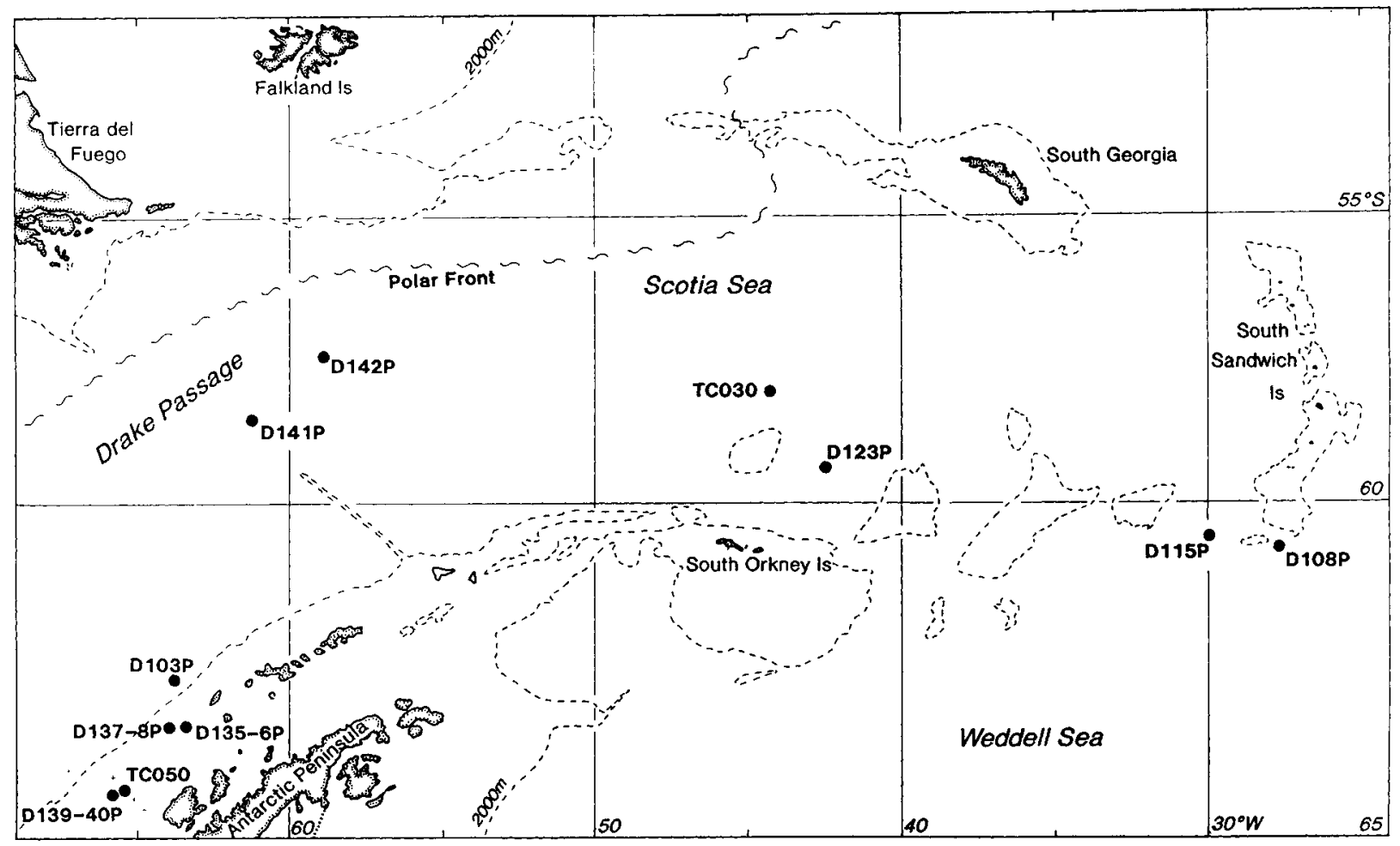

Fig. 1. Location map.

from the Scotia Sea to the Southwest Atlantic at about $45^{\circ} \mathrm{W}$. AABW $\left(\theta=<0.0^{\circ} \mathrm{C} ; \quad S=34.65-34.67 \mathrm{ppt}\right)$ flows eastwards in the northern limb of the cyclonic Weddell Gyre in the Northern Weddell Sea (Deacon, 1979). Some AABW flows into the southern Scotia Sea (Gordon, 1971; Jordan \& Pudsey, 1992 (and references therein)). Indeed, cold deep water of Weddell Sea type has been detected as far west as the South Shetlands (Nowlin \& Zenk, 1988). CPDW and AABW meet at the so-called Weddell-Scotia Confluence (Patterson \& Sievers, 1980), which widens and becomes more diffuse east of the South Orkneys (Foster \& Middleton, 1984).
Comparatively little is known of the shallow water-masses of the study area. However, unpublished expendable bathythermograph (XB'T) measurements show bottom temperatures to be around $1.3^{\circ} \mathrm{C}$. This suggests that the Antarctic Peninsula Shelf, unlike other shelf areas around the Antarctic, is not a reservoir of cold, dense water (Kilworth, 1983).

Material. Fourteen surface samples were made available for foraminiferal analysis through the good offices of the British Antarctic Survey, together with another ten shallow subsurface samples (which were ignored other than for systematic purposes as they were too few in

\begin{tabular}{lcclcl}
\hline Sample & Latitude & Longitude & \multicolumn{1}{c}{ Area } & Depth (m) & Lithology \\
\hline D103P & $62^{\circ} 42^{\prime} \mathrm{S}$ & $63^{\circ} 49^{\prime} \mathrm{W}$ & Antarctic Peninsula Slope & 4200 & Silty mud \\
D108P & $60^{\circ} 44^{\prime} \mathrm{S}$ & $27^{\circ} 37^{\prime} \mathrm{W}$ & South Sandwich & $3000-3200$ & Ashy mud \\
D115P & $60^{\circ} 31^{\prime} \mathrm{S}$ & $29^{\circ} 56^{\prime} \mathrm{W}$ & South Sandwich & $2425-2700$ & Ashy mud* 1 \\
D123P & $59^{\circ} 23^{\prime} \mathrm{S}$ & $42^{\circ} 28^{\prime} \mathrm{W}$ & Scotia Sea & 2900 & Silty ooze \\
D135P & $63^{\circ} 25^{\prime} \mathrm{S}$ & $63^{\circ} 25^{\prime} \mathrm{W}$ & Antarctic Peninsula Shelf & $340-550$ & Ashy mud \\
D136P & $63^{\circ} 25^{\prime} \mathrm{S}$ & $63^{\circ} 28^{\prime} \mathrm{W}$ & Antarctic Peninsula Shelf & 500 & Silty mud \\
D137P & $63^{\circ} 25^{\prime} \mathrm{S}$ & $64^{\circ} 02^{\prime} \mathrm{W}$ & Antarctic Peninsula Shelf & 200 & Crystal-vitric ash \\
D138P & $63^{\circ} 23^{\prime} \mathrm{S}$ & $64^{\circ} 06^{\prime} \mathrm{W}$ & Antarctic Peninsula Shelf & 280 & Vitric ash \\
D139P & $64^{\circ} 24^{\prime} \mathrm{S}$ & $65^{\circ} 47^{\prime} \mathrm{W}$ & Antarctic Peninsula Shelf & 500 & Sandy mud \\
D140P & $64^{\circ} 24^{\prime} \mathrm{S}$ & $65^{\circ} 46^{\prime} \mathrm{W}$ & Antarctic Peninsula Shelf & $390-480$ & Sandy mud \\
D141P & $58^{\circ} 35^{\prime} \mathrm{S}$ & $61^{\circ} 13^{\prime} \mathrm{W}$ & Drake Passage & $1960-2700$ & Sandy mud \\
D142P & $57^{\circ} 29^{\prime} \mathrm{S}$ & $58^{\circ} 54^{\prime} \mathrm{W}$ & Drake Passage & $2550-3000$ & Sandy mud \\
$878 T C 03005 \mathrm{~cm}$ & $58^{\circ} 06^{\prime} \mathrm{S}$ & $44^{\circ} 17^{\prime} \mathrm{W}$ & Scotia Sea & 2730 & Mud-bearing ooze \\
$878 T C 050 \mathrm{CC} * 2$ & $64^{\circ} 19^{\prime} \mathrm{S}$ & $65^{\circ} 27^{\prime} \mathrm{W}$ & Antarctic Peninsula Shelf & 575 & Muddy ooze \\
\hline
\end{tabular}

Table 1. Sample database. *1 Diatom evidence indicates that this sample might be latest Pliocene to Early Pleistocene, rather than Holocene, in age; $* 2$ from core catcher (within $20 \mathrm{~cm}$ of sediment surface). 
number to provide any meaningful regional stratigraphic or palaeoenvironmental information).

Two of the samples $(878 \mathrm{TC} 0300-5 \mathrm{~cm}$ and $878 \mathrm{TC} 050 \mathrm{CC})$ were from trigger cores. The remaining twelve (prefixed D) were obtained opportunistically using a pipe dredge rigged beneath a rock dredge being dragged up slope in order to sample hard rocks (basalts, metasediments, etc.) in connection with various tectonic studies. A pipe dredge deployed like this (see also Kidd et al. (1990)) can collect a large quantity (up to 30-401) of soft sediment, of which $1-21$ is normally retained for study. It probably fills up almost immediately on striking the sea-floor rather than gradually over a range of depths. However, it can sink into soft sdeiment under its own weight and retrieve sediment from the shallow subsurface rather than from the surface. As noted below, the sample from Station D115P could be of Latest Pliocene-Early Pleistocene, rather than Holocene, age.

Methods. $10 \mathrm{~cm}^{3}$ splits of the study samples, stained for live protoplasm (using Rose Bengal), were disaggregated using standard micropalaeontological techniques. The dried disaggregated material was then passed through a nest of sieves (the finest one of which has a $75 \mu \mathrm{m}$ mesh), and the benthonic foraminifera from each sieve fraction were picked, sorted and identified.

\section{RESULTS}

The semiquantitative distribution of benthonic foraminiferal species in the studied samples is shown in Table 2. Note that all of the species were only recorded 'dead' (unstained by Rose Bengal).

\section{Antarctic Peninsula Shelf}

The seven samples from the Antarctic Peninsula Shelf are from water depths of 200-575 $\mathrm{m}$ (Table 1). At the sampling stations, lithologies vary from oozes and silty and sandy muds to ashy muds and crystal and/or vitric volcanic ashes (some are situated on the flanks of volcanoes) (Table 1). At D140P, the bottom temperature is $1.3^{\circ} \mathrm{C}$, and the current velocily up $1025 \mathrm{~cm} \mathrm{~s}^{-1}$.

The Antarctic Peninsula Shelf samples are generally characterized by low benthonic foraminiferal abundance and diversity. One (D139P) is barren. Agglutinating and calcareous benthonic foraminifera occur in equal proportions. Rare planktonic foraminifera (Neogloboquadrina pachyderma) and locally abundant siliceous plankton (diatoms) also occur.

Abundance and diversity are highest in D140P (480 m) and D135P $(550 \mathrm{~m})$, which are situated on topographic 'highs' on the deeper parts of the shelf. Conspicuous benthonic foraminiferal taxa, common or abundant in one or other of these samples, include Hormosininae div. spp., Quinqueloculina spp. and Trifarina angulosa.

\section{Drake Passage}

The two samples from the Drake Passage are from water depths of $2700-3000 \mathrm{~m}$. At both the sampling stations, the lithologies are 'sandy muds', the bottom temperature 0 to $-0.5^{\circ} \mathrm{C}$, and the current 'strong'. The samples are characterized by moderate benthonic foraminiferal abun- dance and diversity. Agglutinating and calcareous benthonic foraminifera occur in equal proportions. The most conspicuous species are Martinottiella communis, Pyrgo murrhina, Uvigerina sp. and Cibicides ex gr. lobatulus. Abundant planktonic foraminifera (Globigerina bulloides, Globorotalia spp., Neogloboquadrina pachyderma) also occur.

\section{South Sandwich}

The two samples from South Sandwich are from water depths of $2700-3200 \mathrm{~m}$. At both the sampling stations, lithologies are 'diatom-bearing ashy muds'. At D108P, the bottom temperature is 0 to $-0.5^{\circ} \mathrm{C}$, and the current velocity $4-5 \mathrm{~cm} \mathrm{~s}^{\prime}$.

The sample from D108P is characterized by low to moderate benthonic foraminiferal abundance and diversity. Agglutinating foraminifera predominate, and indeterminate astrorhizids are common. Planktonic foraminifera (Neogloboquadrina pachyderma) and diatoms also occur.

The sample from D115P is also characterized by low to moderate benthonic foraminiferal abundance and diversity, with agglutinating foraminifera predominant. Planktonic foraminifera (Neogloboquadrina pachyderma) and diatoms also occur. The diatoms include Actinocyclus ingens, Coscinodiscus elliptopora and ?reworked Denticulopsis sp., indicating that this sample could be of Latest PlioceneEarly Pleistocene, rather than Holocene, age.

\section{Scotia Sea}

The two samples from the Scotia Sea are from water depths of $2730-2900 \mathrm{~m}$. At D123P, the lithology is a 'silty ooze', and the bottom temperature is 0 to $-0.3^{\circ} \mathrm{C}$. At $878 \mathrm{TC} 030$, the lithology is a 'mud-bearing ooze'. The samples are characterized by low benthonic foraminiferal abundance and diversity. Only agglutinating species are found. Cribrostomoides subglobosus and Martinottiella communis are common in D123P $(2900 \mathrm{~m})$. Diatoms are abundant in both D123P and 878TC030.

\section{Antarctic Peninsula Slope}

The sample from the Antarctic Peninsula Slope is from a water depth of $4200 \mathrm{~m}$. The lithology at the sampling station is a 'silty mud'. The bottom temperature is $0.2-0.4^{\circ} \mathrm{C}$, and the current velocity up to $10 \mathrm{cms}$ '. The sample is characterized by low benthonic foraminiferal abundance and diversity. Agglutinating foraminifera predominate. The only calcareous foraminifera found are a single indeterminate benthonic species, and a single reworked Cretaceous planktonic species (Globigerinelloides sp.). Indeterminate astrorhizids, Cribrostomoides subglobosus and Martinottiella communis are all common. Diatoms are again abundant.

\section{DISCUSSION}

Abundance, diversity and assemblage composition, and the effects of calcite dissolution

To summarize the results given above, the study samples as a whole are characterized by low to moderate benthonic foraminiferal abundance and diversity (which may be at least in part attributable to the small sample size). The highest values are associated with mid-shelf topographic 


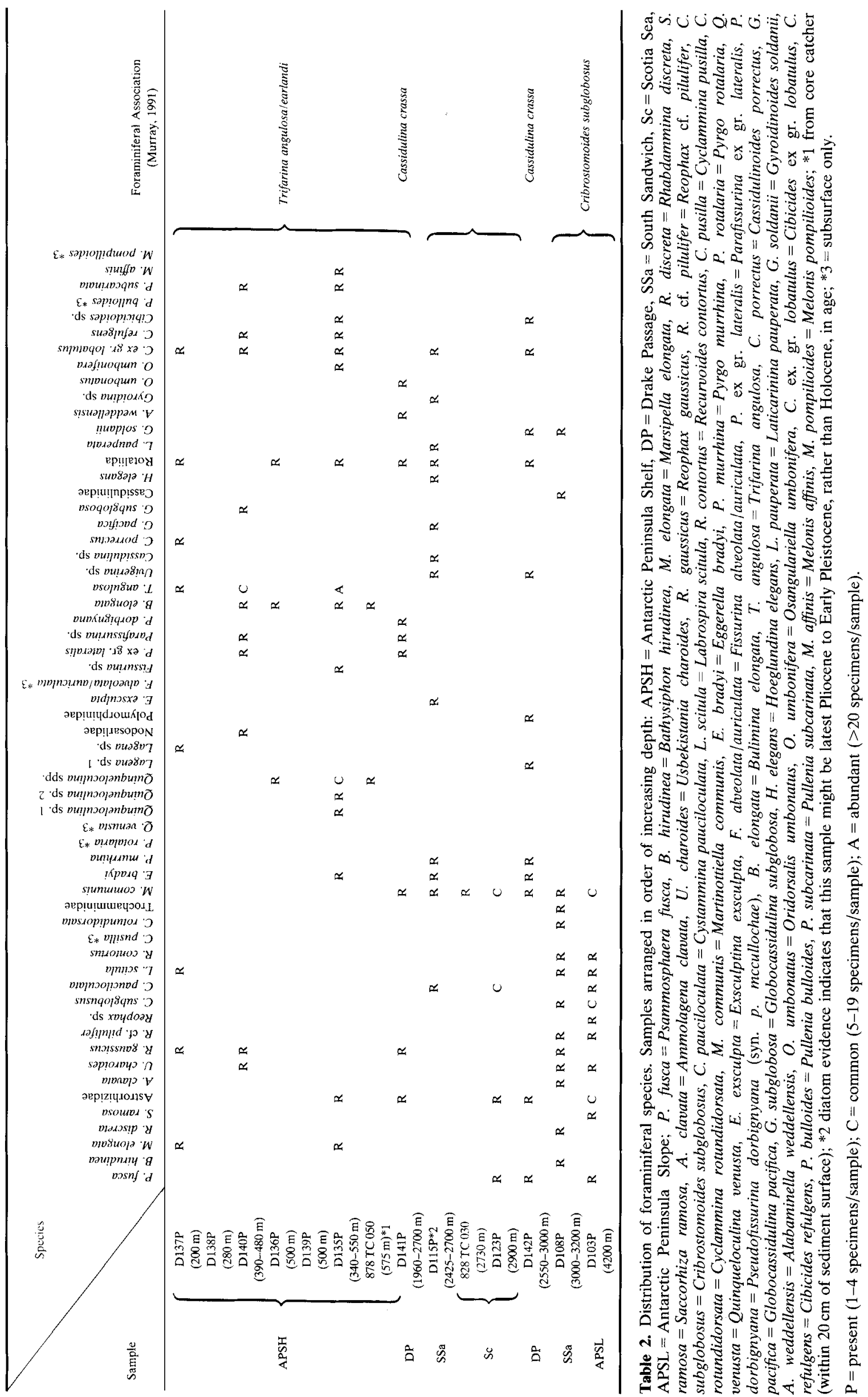


'highs' on the Antarctic Peninsula Shelf ( $480-550 \mathrm{~m}$ ), and in the Drake Passage $(2700-3000 \mathrm{~m})$. Values are low by comparison with those obtained from bathyal and abyssal samples from low to moderate latitudes, but closely comparable with those obtained from bathyal and abyssal samples from high latitudes in the northern hemisphere (Jones, 1984).

Agglutinating and calcareous benthonic species occur in equal proportions in the study samples on the Antarctic Peninsula Shelf $(200-575 \mathrm{~m})$, while agglutinating species generally predominate on the Antarctic Peninsula Slope and in South Sandwich, the Drake Passage and the Scotia Sea $(2700-4200 \mathrm{~m})$. This is probably at least partly explicable in terms of local inhibition of secretion (and/or preservation) of calcareous tests in corrosive, carbon dioxide-enriched bottom water. Note, however, that the relation between the preservation and partial or total dissolution of calcareous foraminifera is dependent less on depth than on water-mass association (see Murray, 1991; see also below).

Plankronic foraminifera (calcareous) and diatoms (siliceous) are widespread and locally abundant in the study samples. Planktonic foraminifera are most common in the Drake Passage $(2700-2900 \mathrm{~m})$, where they occur to the total exclusion of diatoms. Diatoms are most common in the Scotia Sea $(2730-2900 \mathrm{~m})$, and on the Antarctic Peninsula Slope $(4200 \mathrm{~m})$, where they occur to the total exclusion of planktonic foraminifera (possibly because of dissolution effects at or near the local calcite compensation depth (CCD).

\section{Characteristic assemblages and their relationships to water-masses}

Conspicuous benthonic foraminiferal taxa, common or abundant in one or more samples, include Hormosininae div. spp., Quinqueloculina spp. and Trifarina angulosa (Antarctic Peninsula Shelf, 480-550 m), Pyrgo murrhina, Uvigerina sp. and Cibicides ex gr. lobatulus (Drake Passage, $2700-3000 \mathrm{~m}$ ), Martinottiella communis (Drake Passage, 2700-3000 m, Scotia Sea, $2900 \mathrm{~m}$, and Antarctic Peninsula Slope, $4200 \mathrm{~m}$ ), Cribrostomoides subglobosus (Scotia Sea, $2900 \mathrm{~m}$, and Antarctic Peninsula Slope, $4200 \mathrm{~m}$ ), and indeterminate astrorhizids (South Sandwich, $3200 \mathrm{~m}$, and Antarctic Peninsula Slope, $4200 \mathrm{~m}$ ).

The Antarctic Peninsula Shelf assemblages locally characterized by Hormosininae div. spp., Quinqueloculina spp., and Trifarina angulosa $(200-575 \mathrm{~m})$ are similar to those of the 'Fresh Shelf Water Facies' of Anderson (1975), the 'Trifarina angulosa Assemblage' of Mackensen et al. (1990), and the 'Trifarina angulosa/earlandi Association' of Murray (1991) (which are typically similarly dominated by calcareous foraminifera, though locally affected by partial dissolution). Mackensen et al. (1990) recorded their Trifarina angulosa Assemblage 'live' and 'dead' at the shelf break and on the uppermost continental slope, and in predominantly sandy sediments (in areas of strong bottom currents) (in the Eastern Weddell Sea). Murray (1991) recorded his Trifarina angulosa/earlandi Association in water depths of $0-2100 \mathrm{~m}$ (348-713 $\mathrm{m}$ in the Weddell Sea), in muddy sandy lithologies, and in bottom temperatures of
-1.9 to $0.6^{\circ} \mathrm{C}$. He inferred a correlation with Fresh Shelf Water, a variant of Antarctic Surface Water occurring in ice-free areas in the Weddell Sea.

The Drake Passage assemblages characterized by Pyrgo murrhina, Uvigerina sp. and Cibicides ex gr. lobatulus $(2700-3000 \mathrm{~m})$ are similar to those of the 'Deep Water Calcareous-Arenaceous Facies' of Anderson (1975) and the 'Cassidulina crassa Association of Murray (1991) (which are dominated by calcareous foraminifera). Murray (1991) recorded his Cassidulina crassa Association in water depths of 50-4008 $\mathrm{m}$ (104-4008 $\mathrm{m}$ in the Drake Passage and Scotia Sea), in fine sandy lithologies, and in bottom temperatures of -1.9 to $0.6^{\circ} \mathrm{C}$ and salinities of $33.96-35.19 \mathrm{ppt}$. These temperature and salinity ranges embrace those of both CPDW and AABW.

The South Sandwich assemblage, characterized by indeterminate astrorhizids $(3200 \mathrm{~m})$, and the Antarctic Peninsula Slope assemblage, characterized by indeterminate astrorhizids, Cribrostomoides subglobosus and Martinottiella communis $(4200 \mathrm{~m})$, are similar to the 'Abyssal Facies' of Anderson (1975), the 'Cribrostomoides subglobosus Assemblage' of Mackensen et al. (1990) and the 'Cribrostomoides subglobosum Association' of Murray (which are dominated by agglutinating foraminifera). Mackensen et al. (1990) recorded their Cribrostomoides subglobosus Assemblage 'live' on the continental terrace and abyssal plain between $2500-3000 \mathrm{~m}$ (in the Eastern Weddell Sea). Interestingly, they noted that '... because of rapid disintegration of the empty tests of this ... species [Cribrostomoides subglobosus] a predominantly calcareous fauna characterised by Oridorsalis umbonatus ... comprises the dead assemblage .... The poor preservation potential of some agglutinating species is also alluded to by Jones (1984) (Eastern North Atlantic) and Schroder (1986) (Western North Atlantic). Murray (1991) recorded his 'Cribrostomoides subglobosum Association' in water depths of $3022-5587 \mathrm{~m}(3022-4099 \mathrm{~m}$ in the Drake Passage and Scotia Sea and $3737 \mathrm{~m}$ in the Weddell Sea). From the data of both Mackensen et al. and Murray, there appears to be a positive correlation with AABW.

The Scotia Sea assemblage, characterized by Martinottiella communis and Cribrostomoides subglobosus $(2900 \mathrm{~m})$, is intermediate in character between the 'Deep Water Calcareous-Arenaceous' and 'Abyssal' Facies of Anderson (1975) or the 'Cassidulina crassa' and 'Cribrostomoides subglobosum' Associations of Murray (1991) (see above). Murray (1991) inferred no correlation between foraminiferal associations and water-masses in the Scotia Arc area, commenting that there... the distribution of water masses is complex and poorly understood....

\section{CONCLUSIONS}

The study samples, from water depths of $200-4200 \mathrm{~m}$ on the Antarctic Peninsula Shelf and Slope and adjacent areas of the Western Antarctic Ocean, are characterized by generally low to moderate benthonic foraminiferal abundance and diversity (which may be at least in part attributable to the small sample size). Agglutinating and calcareous benthonic species occur in equal proportions in the study samples from 
$200-575 \mathrm{~m}$, while agglutinating species generally predominate in the samples from $2700-4200 \mathrm{~m}$. The low abundance and diversity values and shallow threshold to agglutinatedominated assemblages may both be related to inhibition of secretion (and/or preservation) of calcareous tests in corrosive bottom waters.

Antarctic Peninsula Shelf assemblages, locally characterized by Hormosininae div. spp., Quinqueloculina spp., and Trifarina angulosa $(200-575 \mathrm{~m})$, are similar to those of the 'Fresh Shelf Water Facies' of Anderson (1975), the 'Trifarina angulosa Assemblage' of Mackensen et al. (1990), and the 'Trifarina angulosa/earlandi Association' of Murray (1991), which may be correlated with Fresh Shelf Water (a variant of Antarctic Surface Water occurring in ice-free areas in the Weddell Sea).

Drake Passage assemblages, characterized by Pyrgo murrhina, Uvigerina sp. and Cibicides ex gr. lobatulus $(2700-3000 \mathrm{~m})$, are similar to those of the 'Deep Water Calcareous-Arenaceous Facies' of Anderson (1975) and the 'Cassidulina crassa Association' of Murray (1991), which can be correlated with either CPDW or AABW.

The South Sandwich assemblage, characterized by indeterminate astrorhizids $(3200 \mathrm{~m})$, and the Antarctic Peninsula Slope assemblage, characterized by indeterminate astrorhizids, Cribrostomoides subglobosus and Martinottiella communis $(4200 \mathrm{~m})$, are similar to the 'Abyssal Facies' of Anderson (1975), the 'Cribrostomoides subglobosus Assemblage' of Mackensen et al. (1990), and the 'Cribrostomoides subglobosum Association' of Murray (1991), which appear to be correlated with AABW.

The Scotia Sea assemblage, characterized by Martinottiella communis and Cribrostomoides subglobosus $(2900 \mathrm{~m})$, is intermediate in character between the 'Deep Water Calcareous-Arenaceous' and 'Abyssal' Facies of Anderson (1975) or the 'Cassidulina crassa' and 'Cribrostomoides subglobosum' Associations of Murray (1991).

\section{ACKNOWLEDGEMENTS}

Grateful thanks are due to the British Antarctic Survey for providing the study samples, to BAS and the British Petroleum Company PLC for granting permission to publish (and for providing preparation facilities), and to Mairead Rutherford of BP, who produced the tables. The constructive criticism of Prof. F. T. Banner is also gratefully acknowledged.

\section{Manuscript received August 1992 Manuscript accepted June 1993}

\section{REFERENCES}

Anderson, J. B. 1975. Ecology and Distribution of Foraminifera in the Weddell Sea of Antarctica. Micropaleontology, 21(1): 69-96.

Bandy, O. L. \& Echols, J. 1964. Antarctic Foraminiferal Zonation. Antarctic Research Series, 1: 73-91.

Barker, P. F., Kennett, J. P. et al. 1988. Weddell Sea Palaeoceanography: Preliminary Results of ODP Leg 113. Palaeogeography, Palaeoclimatology, Palaeoecology, 67: 75-102.
Brady, H. B. 1884. Report on the Foraminifera Dredged by H.M.S Challenger During the Years 1873-1876. Reports of the Scientific Results of the Voyage of H.M.S. Challenger, Zoology, 9: 1-184.

Brönnimann, P. \& Whittaker, J. E. 1988. The Trochamminacea of the Discovery Reports. British Museum (Natural History), London.

Deacon, G. E. R. 1979. The Weddell Gyre. Deep-Sea Research, 26: 981-995.

Earland, A. 1933. Foraminifera. Part 2. South Georgia. 'Discovery Reports', 6: 27-138.

Earland, A. 1934. Foraminifera. Part 3. The Falklands Sector of the Antarctic (excluding South Georgia). 'Discovery Reports', 10: $1-208$.

Earland, A. 1936. Foraminifera. Part 4. Additional Records from the Weddell Sea Sector from Material Obtained by the S. Y. Scotia. 'Discovery Reports', 13: 1-76.

Echols, R. J. 1971. Distribution of Foraminifera in Sediments of the Scotia Sea Area, Antarctic Waters. Antarctic Research Series, 15: 93-168.

Echols, R. J. \& Kennett, J. P. 1973. Distribution of Foraminifera in the Surface Sediments. Antarctic Map Folio Series, 17: 13-17.

Fillon, R. H. 1974. Late Cenozoic Foraminiferal Palaeoecology of the Ross Sea, Antarctica. Micropaleontology, 20(2): 129-151.

Foster, T. D. \& Middleton, J. H. 1984. The Oceanographic Structure of the Eastern Scotia Sea-1. Physical Oceanography. Deep-Sea Research, 31: 529-550.

Gordon, A. L. 1971. Oceanography of Antarctic Waters. In Reid, J. L. (Ed.) Antarctic Oceanography, 169-203 Antarctic Research Series, No. 15.

Herb, R. 1971. Distribution of Recent Benthonic Forminifera in the Drake Passage. Antarctic Research Series, 17: 251--300.

Heron-Allen, E. \& Earland, A. 1922. Protozoa. Part 2. Foraminifera. Natural History Reports of the British Antarctic 'Terra Nova' Expedition, 6: 25-268.

Heron-Allen, E. \& Earland, A. 1929. Some New Foraminifera from the South Allantic, 2. Journal of the Royal Microscopical Society, 49: 324-334.

Heron-Allen, E. \& Earland, A. 1932. Foraminifera. Part 1. The Ice-Frec Area of the Falkland Islands and Adjacent Seas. 'Discovery Reports', 4: 291-460.

Jones, R. W. 1984. Late Quaternary Foraminifera from Deep Water Sites in The North-East Atlantic and Arctic. Unpublished Doctoral Thesis, University College of Wales, Aberystwyth.

Jordan, R. W. \& Pudsey, C. J. 1992. High-Resolution Diatom Stratigraphy of Quaternary Sediments from the Scotia Sea. Marine Micropaleontology, 19(3): 201-237.

Kellogg, T. B., Osterman, L. \& Stuiver, M. 1979. Late Quaternary Sedimentology and Benthic Foraminiferal Paleoecology of the Ross Sea, Antarctica. Journal of Foraminiferal Research, 9(4): $322-335$.

Kennett, J. P. 1967. New Foraminifera from the Ross Sea, Antarctica. Contributions from the Cushman Foundation for Foraminiferal Research, 18: 133-135.

Kennett, J. P. 1968. Ecology and Distribution of Foraminifera. The Fauna of the Ross Sea, Part 6. Bulletin, New Zealand Department of Scientific and Industrial Research, 186: 1-48.

Kidd, R. B., Huggett, Q. J. \& Ramsay, A. T. S. 1990. The Status of Geological Dredging Techniques. In Hailwood, E. A. \& Kidd, R. B. (Eds), Marine Geological Surveying and Sampling, 131-143, Kluwer Academic Publishers, Dordrecht.

Kilworth, P. D. 1983. Deep Convection in the World Ocean. Review of Geophysics and Space Physics, 21: 1-26.

Lena, H., 1975. Foraminiferos Bentonicos del area de Isla Elefante (Antartida). Physis, Secc. A, Buenos Aircs, 34(89): 405-431.

Lena, H. 1980. Foraminiferos Bentonicos del Noroeste de la Peninsula antartico. Physis, Secc. A, Buenos Aires, 39(96): 9-20.

Lindenberg, H. G. \& Auras, A. 1984. Distribution of Arenaceous Foraminifera in Depth Profiles of the Southern Ocean (Kerguelen Plateau Area). Palaeogeography, Palaeoclimatology, Palaeoecology, 48: 61-106.

Mackensen, A., Grobe, H., Kuhn, G. \& Fütterer, D. K. 1990. 
Benthic Foraminiferal Assemblages from the Eastern Weddell Sca between 68 and $73^{\circ} \mathrm{S}$ : Distribution, Ecology and Fossilisation Potential. Marine Micropaleontology, 16(3/4): 241-283.

McKnight, W. M. 1962. The Distribution of Foraminifera off parts of the Antarctic Coast. Bulletin of American Paleontology, 44: 65-158.

Milam, R. W. \& Anderson, J. B. 1981. Distribution and Ecology of Recent Benthonic Foraminifera of the Adelie-George $V$ Continental Shelf and Slope, Antarctica. Marine Micropaleontology, 6(3): 297-325.

Murray, J. W. 1991. Ecology and Palaeoecology of Benthic Foraminifera. Longman Scientific and Technical.

Nomura, R. 1983. Foraminifera from the Raised Beach Deposits on the East Coast of Lutzow-Holm Bay, Antarctica. Memoirs, National Institute of Polar Research, Special Issue, 28: 219-230.

Nomura, R. 1984. Cassidulinidae (Foraminifera) from the Eastern Part of Lutzow-Holm Bay, Antarctica. Transactions and Proceedings of the Paleontological Society of Japan, NS, 136: 492-501.

Nowlin, W. D., Jr. \& Zenk, W. 1988. Westward Bottom Currents along the Margin of the South Shetland Island Arc. Deep-Sea Research, 35: 269-301.

Osterman, L. \& Kellogg, T. B. 1979. Recent Benthic Foraminiferal Distributions from the Ross Sea, Antarctica: Relation to Ecologic and Oceanographic Conditions. Journal of Foraminiferal Research, 9(3): 250-269.

Parr, W. J. 1950. Foraminifera. Reports of the B.A.N.Z. Antarctic Research Expedition, Series B (Zoology \& Botany), 5: 233-392.

Patterson, S. L. \& Sievers, H. A. 1980. The Weddell-Scotia Confluence. Journal of Physical Oceanography, 10: 1584-1610.

Pflum, C. E. 1966. The Distribution of Foraminifera in the Eastern Ross Sea, Amundsen Sea and Bellingshausen Sea, Antarctica. Bulletin of American Paleontology, 50: 151-209.

Pudsey, C. J., Barker, P. F. \& Hamilton, N. 1988. Weddell Sea Abyssal Sediments: a Record of Antarctic Bottom Water Flow. Marine Geology, 81: 289-314.

Pudsey, C. J., Murray, J. W. \& Ciesielski, P. F. 1987. Late Pliocene to Quaternary Sedimentation on the South Orkney Shelf. British Antarctic Survey Bulletin, 77: 81-97.

Quilty, P. 1985. Distribution of Foraminiferids in Sediments of Prydz Bay, Antarctica. South Australia Department of Mines and Energy, Special Publication, 5: 329-340.

Saidova, K. M. 1961. Quantitative Distribution of Benthic Foraminifera off Antarctica. Oceanology, 139: 769 [in Russian].

Schroder, C. J. 1986. Deep-Water Arenaceous Foraminifera in the Northwest Atlantic Ocean. Canadian Technical Report of Hydrography and Ocean Sciences, 71: 1-191.

Schroder-Adams, C. J. 1990. High Latitude Agglutinated Foraminifera: Prydz Bay (Antarctica) vs. Lancaster Sound (Canadian Arctic). In Hemleben, C., Kaminski, M. A., Kuhnt, W. \& Scott, D. B. (Eds), Paleoecology, Biostratigraphy, Paleoceanography and Taxonomy of Agglutinated Foraminifera, 315-343, Kluwer Academic Publishers, Dordrecht.

Shchedrina, Z. G. 1979. Fuana of Agglutinated Foraminifera of the South Hemisphere from the Material of the Soviet Antarctic Expedition (1955-1966). Antarktika, 18: 144-174.

Sievers, H. A. \& Nowlin, W. D., Jr. 1984. The Stratification of Water Masses at Drake Passage. Journal of Geophysical Research, 89: 10489-10514.

St John, B. (Ed.) 1990. Antarctica as an Exploration FrontierHydrocarbon Potential, Geology, and Hazards. American Association of Petroleum Geologists, Studies in Geology No. 31, Tulsa, Oklahoma.

Theyer, F. 1971. Benthic Foraminiferal Trends, Pacific-Antaretic Basin. Deep-Sea Research, 18: 723-738.

Weston, J. F. \& Murray, J. W. 1984. Benthic Foraminifera as Deep-Sea Water-Mass Indicators. In Oertli, H. (Ed.), Benthos ' 83 (Proceedings of the Second International Symposium on Benthic Foraminifera, Pau, April 1983), 605-610, Elf Aquitaine, Esso REP and Total CFP.

Wiesner, H. 1931. Die Foraminiferen der Deutschen SudpolarExpedition 1901-1903. Deutsche Sudpolar Expedition, Zoologie, 20: $49-165$. 